\title{
INVESTMENT ATTRACTIVENESS OF AGRICULTURAL SECTOR OF UKRAINIAN REGION IN MODERN CONDITIONS OF SOCIAL AND ECONOMIC DEVELOPMENT
}

\author{
Nadiia Davydenko', Alina Buriak² \\ National University of Life and Environmental Sciences of Ukraine, Ukraine \\ Inna Demianenko3 \\ National University of Food Technologies, Ukraine
}

\begin{abstract}
It is proved that investment attractiveness of regions is an indisputable factor in the stable socioeconomic development of the country. The purpose of the study is to analyse investment attractiveness of region and to substantiate proposals for improving investment attractiveness of Cherkasy region. The subject of the study was peculiarities of formation and expansion of investment potential in the region. Methodology. The paper is based on the views of prominent domestic and foreign economists. During the research process, the following methods were used: monographic, historical, analysis and synthesis (in theoretical and empirical studies of investment process); systematic (for the systematization of methodological approaches and indicators of investment attractiveness assessment of the region); statistical and graphics (for the analysis of state and trends of investment processes in Ukraine); comparative (for analysing the investment attractiveness of regions). Results. The essence of investment attractiveness of region as aggregate characteristic of conditions of a certain territory of the country is determined, which includes assessment of development level of investment infrastructure, human capital, financial opportunities, which significantly affect the formation of profitability of invested fixed assets and investment risks. Investment attractiveness of an individual region of Ukraine is assessed. It is proved that investigated region is investment-attractive and has a powerful potential for increasing the volume of gross agricultural products and providing the population with quality food products. Practical implications. The main problems connected with the receipt of investments into the economy of the region are determined, ways of their solution are revealed. In order to improve investment attractiveness level of Cherkasy region, we recommend local authorities to work in the following areas: introduction of free funds accumulation mechanism, in particular, in venture funds; creation of innovative risks insurance system; accumulation of public funds within the framework of social and pension insurance systems and their focus on long-term lending of investment activity; strengthening investment activity of population and ensuring guaranteed protection of their savings.
\end{abstract}

Key words: regional economy, investment attractiveness of region, investment potential, investment climate of region.

JEL Classification: Q14, M21, R30

\section{Introduction}

An important role in investment activity strategy plays a scientifically grounded definition of priority investment directions, their compliance with state interests, program objectives of the national revival of Ukraine, rapid overcoming of economic crisis and achievement of stabilization and national economy's growth. They are priority directions of scientific and technological progress, on which investment and innovation activities and resources should be aimed at as much as possible. Only those countries that are able to provide a high level of science, technology, education, culture, an organization of management and labour discipline can apply for

\footnotetext{
Corresponding author:

${ }^{1}$ Department of Finance, National University of Life and Environmental Sciences of Ukraine.

E-mail: davidenk@ukr.net

${ }^{2}$ Department of Finance, National University of Life and Environmental Sciences of Ukraine.

E-mail: alina.v.bu@online.ua

${ }^{3}$ Department of Finance, National University of Food Technologies.

E-mail: i.demyanenko@ukr.net
} 
the development of modern and future high-tech industries (Davidenko, 2011).

In the Ukrainian economy, a difficult situation has arisen in this regard. State that has been depleted as result of corruption, financial crisis, and military actions in the east, loses reliable sources of necessary investments. And now seeking at least with a considerable delay to revive and intensify policy of reproduction as the basis for stabilization and renewal of national commodity production, faced with the opposition of certain political and economic forces. Concentration of financial capital in new structures areas, shadow turnover and banking system, which do not seek productive investments, in fact, inhibits reproduction processes, economic stabilization and growth.

Limited investment resources and unstable capital investment contributed negatively to development and stabilization of the state economy and economy of individual regions.

\section{Review of theory and literature}

Considering peculiarity of the problem, a large number of works were published on the subject of research. According to A. Duka (Duka, 2013), mercantilists made one of the first contributions to the formation and development of investment theory.

Representatives of late mercantilism (Mun, Serra, Montchrestien) asserted the need to invest in those industries that produce export-oriented products in order to achieve positive trade balance (Lukyanenko, 2003).

Establishment of John Keynes connection between consumption, investment, and national income, which he made on the basis of the concept of a multiplier, deserves attention. He also deduced the quantitative relationship between investment and national income based on the multiplier effect or multiplier effect (Keynes, 2002).

Among modern scholars problems of current state and possibilities of optimizing investment potential of the region, its investment attractiveness were investigated by domestic and foreign researchers such as V. Andriichuk, I. Bahrova, L. Borshch, I. Hryshyna, B. Hubskyi, N. Davydenko, B. Epifanov, H. Kozachenko, M. Kozoriz, R. Coase, P. Makarenko, O. Margolin, V. Onyshchenko, I. Rozeman, B. Chub, V. Fedorenko, and others. Aforementioned scientists have developed sound approaches to implementation of regional investment policy, offered their own methods for assessing the level of investment development of the region and its investment attractiveness.

In the works of O. Baranovskyi (2004) and V. Petrushevska (2013), reasons for the lack of attraction process efficiency of foreign investments are revealed. Researchers such as V. Liashenko (2004), Y. Bazhal (2006) researched topic of investment and investment climate. However, given multidimensional nature of topic under study, many of its aspects have not been thoroughly studied. In particular, the issues of assessing investment attractiveness of Ukrainian regions and directions for its improvement remain inadequately investigated.

\section{Analysis of factors characterizing investment attractiveness of the region}

Regional investment attraction policy is defined as one of the main factors that affect not only economic growth efficiency but also content and form of Ukraine's entry into the world economic system.

Investment attractiveness of the region is a virtual concept since the desired one does not always correspond to reality. Assessing investment attractiveness of a particular region, rating agencies take into account not only the natural and productive potential, availability of labour and financial resources but also (usually as a result of surveys) assessments of the political situation in the region, corruption level of officials, judicial protection of entrepreneurship in the territory, etc. Moreover, the opinion of respondents may be polar depending on their personal experience of interaction with structures of state power.

In our opinion, investment attractiveness of the region is an aggregate characteristic of certain territory's conditions of the country, which includes assessment of legal framework development level, investment infrastructure, human capital, a financial capacity that significantly influences the formation of invested capital profitability and investment risks.

Namely, investment attractiveness of region is a combination of factors that predetermine behaviour of existing and potential investors in investing in region's economic development. Factors that determine investment attractiveness of region are:

1) availability of resource and raw material base and features of natural and climatic conditions;

2 ) economic and geographical position of the region and its level of infrastructure provision;

3 ) industrial and scientific specialization of the region;

4) availability of labour potential and level of its qualification;

5) aggregate population purchasing power;

6) development of institutional market structure (exchanges, banks, financial intermediaries, insurance companies, etc.);

7) general state factors (level of political stability, the current system of legislation, taxation system, conditions of activity of foreign investors, etc.).

So, let us take a closer look at all of the above components in order to make a real assessment of investment attractiveness of agricultural sector of the economy of Cherkasy region.

Cherkasy region is located in the central part of Ukraine; its area is 20.9 thousand square $\mathrm{km}$, which is 
$3.46 \%$ of the state (18th place in the country). In the north, it borders Kyiv region, in the south - Kirovohrad region, on the east with Poltava, and Vinnytsia in the west. Due to its geographical location, the region is characterized by developed infrastructure.

The main document for regional development in the medium-term perspective is Cherkasy Region Development Strategy for the period up to 2020, which includes Cherkasy Region Development Strategy Implementation Plan for 2015-2018, which was prepared with the participation of stakeholders of regional development through workshops and discussions that took place during 2014-2015.

Strategy was developed on the basis of the Law of Ukraine "On Stimulating Development of Regions", taking into account State Strategy for Regional Development of Ukraine, Strategy for Sustainable Development "Ukraine - 2020" and other documents, as well as using the best European and Ukrainian experience and experience in implementing the Strategy for Development of Cherkasy Region by 2015.

Between 2010 and 2017, the largest share of all capital investments was used by enterprises of agriculture, forestry, and fisheries (42\% in 2016). In 2017, direct investments came from non-residents from 45 countries. Main investor countries that account for $94.5 \%$ of the total foreign capital include Belize, Cyprus, Germany, the Czech Republic, France, Spain, the United Kingdom, Estonia, and the Netherlands.

The agroindustrial complex of the region has potential to increase the volume of gross production of agriculture, providing people with quality food products. Over the past five years, Cherkasy region's agriculture is characterized by profitability. The main directions of agriculture:

- crop production (grains and technical crops, fruitbearing plantations, vegetables);

- livestock breeding (cattle, pigs, poultry).
Analysis of crop production sector shows that for the years of 2014-2016, crop area for agricultural crops is almost unchanged, with the exception of forage crops, which ceased to grow in 2016 (since yield was very low), which were replaced by fruit and berries 5,500 hectares of land were allocated in the same year of 2016.

The largest amount of production is attributed to grain and leguminous crops, namely, 40793.0 thousand tons in 2016, and the smallest one - to fruits and berries. Fodder crops, although they had a sown area in 2014 and 2015 more than 100 thousand hectares, did not produce anything.

Sugar beet (factory) had the highest yield in the Cherkasy region. So, from 1 hectare of harvesting area, you can get an average of 460 thousand. Potatoes and open-ground vegetables also have high yields, grain and legume with the lowest yield, but due to their cropping area, this region's culture is sufficiently covered.

Regarding the livestock sector in the Cherkasy region, it reflects the general picture of Ukraine: the number of livestock and poultry reduces every year. For example, if we compare the number of cattle in 2016 to 2014, we can say that it decreased by $8.4 \%$. Significantly situation is better with a number of poultry and pigs.

In general, the Cherkasy region is an important part of livestock production of our state because, in terms of meat production, the region occupies the first place in Ukraine, milk - 8, and eggs - 9 .

\section{SWOT-analysis of investment attractiveness of agricultural sector of Cherkasy region's economy}

Formation of the investment climate in the region depends on improving investment attractiveness. To find out investment attractiveness of agricultural enterprises in the region, it is necessary to determine where exactly the most favourable microclimate of the

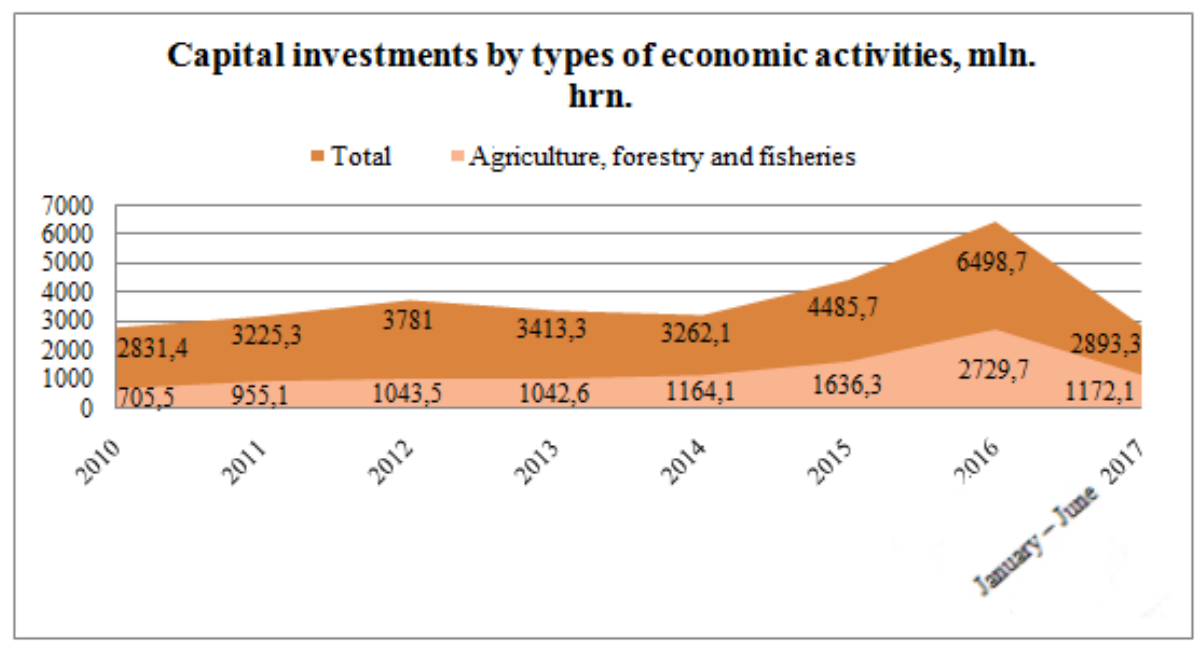

Source: developed by the author on the basis of data of the Main Department of Statistics of Cherkasy region 
region is. It is based on the definition of investment attractiveness in terms of financial indicators, land use, and volume of external and internal investment in agricultural enterprises.

Analysis of investment processes suggests that financial resources are invested mainly in large enterprises. However, small and medium-sized farms, which are common for Cherkasy region, also require investment. Because of agricultural enterprises management specifics in Cherkasy region, in the vast majority, there are very small (private peasant farms), small (private peasant farms, farms) and average production (farms, private agricultural enterprises). There are only a few large agricultural farms in Cherkasy region (Table 1).

According to results of 2016, agricultural production was carried out by 569 agricultural enterprises, which cultivated 65 percent of the total area of arable land, 1424 farms, of which 1190 farms have in use more than 151.4 thousand hectares of agricultural land (on average, one enterprise have 127.2 ha of land). According to operational statistics, the volume of gross agricultural production in all categories of farms grew by $2.1 \%$, in agricultural enterprises - by $3.2 \%$. According to volume index, Cherkasy region is sixteenth, production per capita - the third, in terms of production - the sixth. The share of agricultural production to the national level is $5.9 \%$.

Therefore, it is further expedient to assess investment attractiveness of agricultural sector of the economy of Cherkasy region using the SWOT-analysis method.

The great advantage of Cherkasy region is the presence of large areas of high productive land and favourable natural and climatic conditions that contribute to the cultivation of many crops. In the context of current
Table 1

A number of agricultural enterprises in Cherkasy region in 2017

\begin{tabular}{|l|c|c|}
\hline Name of district & $\begin{array}{c}\text { Number of } \\
\text { agricultural } \\
\text { enterprises }\end{array}$ & $\begin{array}{c}\text { Overall rank in } \\
\text { district ranking }\end{array}$ \\
\hline Horodyshche & 65 & 16 \\
\hline Drabiv & 141 & 3 \\
\hline Zhashkiv & 110 & 10 \\
\hline Zvenyhorodka & 115 & 8 \\
\hline Zolotonosha & 98 & 10 \\
\hline Kamianka & 83 & 11 \\
\hline Kaniv & 97 & 14 \\
\hline Katerynopil & 66 & 12 \\
\hline Korsun-Shevchenkivskyi & 89 & 15 \\
\hline Lysianka & 166 & 13 \\
\hline Mankivka & 126 & 4 \\
\hline Monastyryshche & 97 & 12 \\
\hline Smila & 115 & 8 \\
\hline Talne & 144 & 2 \\
\hline Uman & 66 & 15 \\
\hline Khrystynivka & 119 & 7 \\
\hline Cherkasy & 49 & 17 \\
\hline Chyhyryn & 123 & 6 \\
\hline Chornobai & 112 & 9 \\
\hline Shpola & 2 & 22 \\
\hline Vatutine city & 21 & 18 \\
\hline Zolotonosha city & 8 & 21 \\
\hline Kaniv city & 14 & 20 \\
\hline Smila city & 19 & 19 \\
\hline Uman city & 2279 & 5 \\
\hline Cherkasy city & & x \\
\hline Total in the region & 19 & \\
\hline
\end{tabular}

Source: calculated by the authors (Main Department of Statistics of Cherkasy region)

Table 2

\section{SWOT-analysis of investment attractiveness of agrarian sector of Cherkasy region's economy}

\begin{tabular}{|c|c|}
\hline Strong sides & Week sides \\
\hline $\begin{array}{l}\text { 1. Moderate natural and climatic conditions for } \\
\text { agricultural production. } \\
\text { 2. Relief of the territory and high-performance soils. } \\
\text { 3. Favourable geographic location of the region. } \\
\text { 4. Significant manufacturing experience. } \\
\text { 5. Availability of old industrial zones for investing. } \\
\text { 6. Availability of research institutions in branches of } \\
\text { the agro-industrial complex. } \\
\text { 7. Stable development of agro-industrial complex. } \\
\text { 8. Developed processing sector of agricultural } \\
\text { products. }\end{array}$ & $\begin{array}{l}\text { 1. Significant imbalances between districts' economic development. } \\
\text { 2. High degree of deterioration of material and technical base of enterprises. } \\
\text { 3. Lack of development of agrarian infrastructure (vegetable and fruit storage). } \\
\text { 4. High concentration of agricultural lands (in hands of latifundists), lack of control } \\
\text { over the use of land resources. } \\
\text { 5. Low innovative activity of the economic complex. } \\
\text { 6. Lack of foreign investment. } \\
\text { 7. High share of seasonal unemployed. } \\
\text { 8. Storage on the territory of the region of unknown, unsuitable, and prohibited for } \\
\text { using chemical means of protection of plants (waste, pesticides), requiring urgent } \\
\text { disposal. }\end{array}$ \\
\hline Possibilities & Threats \\
\hline $\begin{array}{l}\text { 1. Transfer of production from East Ukraine in the } \\
\text { Cherkasy region. } \\
\text { 2. Output to EU markets } \\
\text { 3. Devaluation of national currency will enhance the } \\
\text { competitiveness of ability of exporters. } \\
\text { 4. Cooperation with new foreign partners }\end{array}$ & $\begin{array}{l}\text { 1. High level of unpredictability of inflation due to the instability of the economy. } \\
\text { 2. The inequality of foreign and domestic investors. } \\
\text { 3. High cost of borrowed funds. } \\
\text { 4. Competitive threat associated with the European producers in the market of Ukraine. } \\
\text { 5. Loss of markets focused on Russia. } \\
\text { 6. Loss of personnel associated with the abolition of the visa regime. } \\
\text { 7. Military operations in the East of Ukraine. }\end{array}$ \\
\hline
\end{tabular}

Source: Cherkasy region development strategy for the period up to 2020, supplemented by the authors 
events (European integration, Agreement on the Free Trade Area of Ukraine with the EU), a developed sector of processing agricultural products is a significant plus for the region.

\section{Conclusions}

Investment attractiveness of the region is a set of qualitative and quantitative indicators that comprehensively determine ability to multiply invested capital and is derivative characteristic of investment climate formed under the influence of various factors and determines investors' desire or refusal to invest in investment object.

Cherkasy region is a modern investment-attractive region. The agro-industrial complex has powerful potential for increasing the volume of gross agricultural products and providing the population with quality food products.

Analysis of investment attractiveness of Cherkasy region showed that it is satisfactory, has a significant number of profitable commodity producers. Availability of raw materials for waste from agrarian sector can be used for further processing in order to create sources of alternative energy. Presence of large areas of agricultural land can be used to grow energy plants. In addition, there are energy minerals in the region, companies that have the potential for conversion to alternative fuels, energy production opportunities, using natural energy (water, sun). All this together provides opportunities for the development of alternative energy and energy from renewable sources.

In order for the investor to make a profitable investment in the agrarian sector of this region, it is necessary to eliminate a number of shortcomings, starting with national and most global ones - improving the socioeconomic situation, stabilizing national currency.

A particular attention needs to be paid to the introduction of innovations, which is possible only through legislative and investment support, which in turn will contribute to the development of entire infrastructure.

Access to EU markets will surely help increase agricultural output and increase the quantity of grain, vegetable and fruit storage, and consolidate region as a stable exporter. All of this will have a positive effect on employment in the region, as jobs will be created that will positively affect the welfare of the population.

\section{References:}

Most of Cherkassy region's investments are offshore. Electronic resource. Retrieved from: https://dzvin.news/ bilshist-investytsij-na-cherkaschynu-dayut-ofshory/

Main Department of Statistics of Cherkasy region. Electronic resource. Retrieved from: http://www.ck.ukrstat.gov.ua

Davydenko, N. (2011). Influence of corporate governance system on formation of investment attractiveness of enterprises. Scientific Bulletin of Ukrainian NGO. Series "Economics, Agrarian Management, Business". 1. p. 203-212.

Duka, A. (2013). Technological modernization of economics in the context of J. Schumpeter's theory of economic development. Bulletin of the Kyiv National University named after Taras Shevchenko. 144. p. 10-12.

Keynes, J. (2002). Obschaya teoriya zaynyatosti, protsenta i deneg [General theory of employment, interest and money]. - Moscow: Gelios ARV. (in Russian)

Lukianenko, D. G. (ed) (2003). MIzhnarodna InvestitsIyna dIyalnIst [International investment activity]. Kyyiv b.i. (in Ukrainian)

Cherkasy region development strategy for the period up to 2020. Electronic resource. Retrieved from: http: //www.ck-oda.gov.ua/docs/2015/strategy_2020.pdf 